\title{
SPEENIONE NADZIEJE
}

\section{IN STATU NASCENDI}

\section{Jan Pawee II a Unia Europejska}

Jan Paweł II na temat Unii Europejskiej wypowiadał się ponad 700 razy ${ }^{1}$. Wielokrotnie podkreślał swoje oczekiwania wobec kierunku, w jakim zmierzać ma integracja europejska. Wyznaczał cele z pozoru nieosiągalne: zjednoczenie Europy w jej geograficznych granicach, traktowanie poszczególnych państw jak członków jednej rodziny, bezwarunkowe poszanowanie praw człowieka oraz ludzkiej godności w każdym aspekcie prawotwórczej działalności. Słowa takie, bez głębokiej wiary w możliwość ich zrealizowania, pozbawione byłyby znaczenia. Nadzieja definiowana jest bowiem jako oczekiwanie spełnienia się czegoś pożądanego i ufność, że to się spełni². Jan Paweł II pokładał więc w integracji europejskiej nadzieje na miarę wielkości niespotykanego wcześniej przedsięwzięcia, jakim jest budowa organizacji ponadnarodowej - zrzeszającej przeszło 507 milionów lu$\mathrm{dzi}^{3}$ różnych kultur, tradycji prawnych, wyznań i języków, przy braku narzucania zwierzchnictwa jednej nacji innym narodom. Zbudowanie sprawnie działającego państwa, złożonego tylko ze społeczności jednorodnej, stanowi ogromne wyzwanie. Do utworzenia organizacji ponadnarodowej, mającej urzeczywistniać w dodatku chrześcijańskie wartości, niezbędne jest głębokie przekonanie o możliwości osiągnięcia celu i spoglądanie w przyszłość z nadzieją.

Dziś, wiele lat po sformułowaniu pewnych postulatów dotyczących integracji europejskiej, można ocenić stopień ich realizacji. Niektóre już się narodziły. Inne są dopiero in statu nascendi ${ }^{4}$. Niniejsza praca stanowi asumpt do dokonania analizy niektórych oczekiwań sformułowanych przez Jana Pawła II pod adresem Europejskiej Wspólnoty Gospodarczej, a dzisiejszej Unii Europejskiej.

\footnotetext{
1 Por. Kościót a Unia Europejska, http://www.niedziela.pl/artykul/9166/Kosciol-a-Unia-Europejska (12.09.2014).

2 Nadzieja, [w:] Słownik języka polskiego, t. 2, red. M. Szymczak, Warszawa 1979, s. 255.

3 Dane za EUROSTAT: http://ec.europa.eu/eurostat.

4 In statu nascendi (łac.) - w trakcie narodzin.
} 


\section{Stolica Apostolska a polityka}

Stosunek Kościoła do polityki wzbudza w opinii publicznej wyjątkowe kontrowersje. Wypowiadanie się przez przedstawicieli duchowieństwa na tematy związane ze sprawowaniem władzy często bywa odbierane jako atak na suwerenność państwa czy „mieszanie się” w sprawy zupełnie odmienne od zasadniczej działalności związku wyznaniowego ${ }^{5}$. Każde słowo hierarchów kościelnych na tematy związane z polityką musi być więc wypowiadane z należytą ostrożnością i odpowiednim dobraniem sformułowań - nawet jeśli pełne nadziei oczekiwania są zgodne z powszechnie uznawanymi zasadami moralnymi. Samo wyrażanie nadziei znaczyłoby przy tym niewiele, gdyby nie dążenie do jej realizacji. $\mathrm{Z}$ tego też względu wymagane jest podejmowanie konkretnych, odpowiednio wyważonych działań, zmierzających do urzeczywistnienia formułowanych postulatów, co znajduje wyraz w nauczaniu hierarchów. Jan Paweł II nie jest jedynym biskupem Rzymu odwołującym się do polityki. Wystarczy wspomnieć chociażby Pawła VI, apelującego do przywódców światowych, by ci przeznaczyli część wydatków ponoszonych na zbrojenia na utworzenie powszechnego funduszu pomocy dla narodów ubogich ${ }^{6}$. Papież akcentował, iż w świecie „nadrozwoju” gospodarczego występuje niedorozwój moralny ${ }^{7}$. O ile ten pierwszy jest osiągany przez technikę, o tyle wyeliminowanie tego drugiego musi nastąpić przez pokładanie nadziei w sprawowanie władzy przez ludzi mądrych: przepełnionych miłością, przyjaźnią, modlitwą i kontemplacją. Podobnie Benedykt XVI wskazywał, że odseparowanie Kościoła od władzy świeckiej wcale nie oznacza niemożliwości wpływania na podejmowane decyzje polityczne. Oznacza jedynie zakaz prowadzenia walk politycznych, co nie wyklucza ksztaltowania moralności osób sprawujących władzę . Franciszek wskazuje wprost, używając przy tym dobitnego języka: dobry katolik miesza się do polityki ${ }^{9}$. Nauczanie Jana Pawła II nie tylko pozostaje spójne z twierdzeniami przedstawionymi powyżej, ale należy stwierdzić, iż poglądy następców papieża Polaka stanowią rozwinięcie jego myśli. Świat przełomu tysiącleci wywołuje w człowieku niepokój. Struktury społeczne są dziś przekształcane przez zupełnie nowe zjawiska ekonomiczne. Zdobycze naukowe w dziedzinie biotechnologii stwarzają coraz pilniejszą potrzebę obrony ludzkiego życia we wszystkich postaciach. Zagubiona opinia publiczna daje wiarę pustym obietnicom zbudowania nowego

5 Por. J. Stróżyk, Palikot chce zamknąć usta Kościołowi, „Przewodnik Katolicki” 2010 nr 45, https://www.przewodnik-katolicki.pl/Archiwum/2010/Przewodnik-Katolicki-45-2010/ Spoleczenstwo/Palikot-chce-zamknac-usta-Kosciolowi (12.09.2014).

6 Por. Paweł VI, enc. Popolorum progressio, 51.

7 Por. tamże, 20.

8 Por. Benedykt XVI, enc. Deus caritas est, 28.

9 Por. Papież: dobry katolik miesza się do polityki, http://www.rp.pl/artykul/1048571. html (12.09.2014). 
społeczeństwa ${ }^{10}$. Jan Paweł II widzi jednak szansę na polepszenie tak zarysowanego świata. Ratunek stanowi nadzieja na podejmowanie stanowczych decyzji politycznych. Takich, które będą sprzyjały rodzinie, ludziom zarówno młodym, jak i starszym, a także człowiekowi zepchniętemu na margines. W tym celu nieodzowna jest, dokonywana przez duchowieństwo, daleko idąca analiza tworzonego prawa, a także - co stanowi postulat odnoszony również do laikatu - wiara w ludzi sprawujących władzę. Nadzieja, że na szczycie struktur państwowych zasiądą politycy, którzy w świecie mnożących się, trudnych wyzwań będą podejmowali „bardzo odpowiedzialne decyzje” ${ }^{11}$. Z przedstawionego rozumowania wyłania się obraz Kościoła nie tylko uprawnionego, ale wręcz zobowiązanego do „mieszania się w politykę" za pomocą kształtowania sumień. Warto zatem zarysować zinstytucjonalizowane formy wpływania Stolicy Apostolskiej na kształt prawa podejmowanego stanowionego we Wspólnotach Europejskich - formalne środki, mające doprowadzić do urzeczywistnienia nadziei na stworzenie lepszego świata.

Już papież Pius XII podpisanie traktatów rzymskich w 1957 roku określił jako „najważniejsze i najbardziej znaczące wydarzenie we współczesnej historii Wiecznego Miasta" ${ }^{12}$. Jan Paweł II postulował, by Kościół był obecny w strukturach wspólnot europejskich $\mathrm{w}$ konkretnej formie instytucjonalnej, a nie tylko przez urzędników - katolików ${ }^{13}$. Dotychczasowe formy obserwowania poczynań Wspólnot przestały bowiem wystarczać. Przy aprobacie Jana Pawła II, 3 marca 1980 roku powstała w Brukseli Konferencja Komisji Episkopatów przy Wspólnotach Europejskich (COMECE), mająca monitorować prawotwórcze działania Unii Europejskiej $^{14}$. Nadzieja na stworzenie organizacji ponadnarodowej, zapewniającej nie tylko rozwój gospodarczy, ale i moralny, doczekała się urzeczywistnienia zinstytucjonalizowanego - ciała opiniującego tworzone regulacje z perspektywy wartości duchowych. Według nauczania Jana Pawła II ingerencja Kościoła w działalność Unii Europejskiej jest usprawiedliwiona samą tylko strukturą jednoczącej się Europy - została ona bowiem oparta na chrześcijańskich wartościach: poszukiwaniu wspólnego dobra i umieszczaniu w centrum działań poszanowania dla ludzkiej godności ${ }^{15}$. Ko-

10 Por. Jan Paweł II, list apost. „motu proprio” o ogłoszeniu św. Tomasza Morusa patronem rządzących i polityków, 4.

11 Tamże.

12 "The most important and significant event in the modern history of the Eternal City" (cyt. za: http://www.comece.org/site/en/whoweare/historyofcomece/article/3681.html [12.09.2014]).

13 Por. Rozpoczęty się Pierwsze Katolickie Dni Społeczne dla Europy, http://magazynfamilia.pl/drukuj/Rozpoczely_sie_Pierwsze_Katolickie_Dni_Spoleczne_dla_Europy,1927,76. html (12.09.2014).

${ }_{14}$ Por. Preambuła Statutu Komisji Episkopatów przy Wspólnocie Europejskiej (COMECE), http://www.comece.org/site/en/whoweare/statutes (12.09.2014).

15 „Motivated by the Christian inspiration of its founding fathers, the European project positioned itself in the search for the common good, placing at the centre of its action the respect for human dignity" (tamże). 
ściół od stuleci żyje pośród narodów tworzących Europę - musi więc interesować się ich losami ${ }^{16}$. Nie powinien jednak badać kształtu instytucjonalnego Unii, ale skupiać się na rozwiązaniach mogących zapewnić wzrastanie duchowe całych społeczeństw. Należy mieć również na uwadze, iż Kościół obecny jest w polityce nie tylko poprzez głos hierarchów, nauczających narody i wyjaśniających prawdy moralne, ale przede wszystkim przez wiernych, wypełniających swe obowiązki należycie, a w przypadku rządzących - miłujących naród. Wiele lat później papież Franciszek rozwinął tę myśl - rządzenie bez miłości nie jest bowiem rządzeniem, lecz co najwyżej wymuszaniem dyscypliny ${ }^{17}$.

\section{Nadzieje spełniane - integracja aż po granice geograficzne Europy}

W 1988 roku do Europejskiej Wspólnoty Gospodarczej należało 12 państw, położonych wyłącznie w obszarze Europy Południowo-Zachodniej (Belgia, Dania, Francja, Grecja, Hiszpania, Holandia, Irlandia, Luksemburg, Portugalia, RFN, Włochy, Wielka Brytania). Żelazna kurtyna nadal istniała, mur berliński miał upaść dopiero za rok. W tym trudnym dla Europy czasie, gdy różnice między Wschodem a Zachodem były szczególnie widoczne, papież Jan Paweł II wystąpił w Parlamencie Europejskim. Jego pełne nadziei przemówienie wydawało się formułowaniem postulatów wręcz niemożliwych do osiągnięcia - wyrażał wiarę, iż europarlamentarzyści w końcu zauważą, że Wschód i Zachód Europy to nie odrębne byty, ale wręcz żywe tkanki o wspólnym kodzie genetycznym. „Płuca", nie tylko mające potencjał, by stworzyć nowy organizm, ale niegdyś nim będące ${ }^{18}$. Był to przejaw głębokiej nadziei na możliwość dokonania daleko idących przemian ustrojowych - tej samej, która umożliwiła Papieżowi wypowiedzenie w trakcie pierwszej pielgrzymki do Polski słów: „Niech zstąpi Duch Twój! Niech zstąpi Duch Twój! I odnowi oblicze ziemi. Tej ziemi! Amen"19.

Dziś, spośród 46 państw europejskich do Unii Europejskiej należy 27 z nich oraz Cypr - formalnie leżący na terenie Azji. Geograficzna powierzchnia Europy wynosi przeszło 10 milionów kilometrów kwadratowych, ale bez europejskiej czę-

16 Por. Przemówienie Jana Pawła II w Parlamencie Europejskim w Strasburgu, 11.10.1988.

17 Por. Papież: dobry katolik..., dz. cyt.

18 „Do reprezentowanych tu dziś narodów w przyszłości będą się mogły z pewnością przyłączyć także inne. Pragnieniem moim - jako najwyższego Pasterza Kościoła powszechnego, który pochodzi ze wschodniej Europy i zna aspiracje ludów słowiańskich, tego drugiego "płuca» naszej wspólnej europejskiej ojczyzny - jest to, by Europa suwerenna i wyposażona w wolne instytucje rozszerzyła się kiedyś aż do granic, jakie wyznacza jej geografia, a bardziej jeszcze historia. Jakże miałbym tego nie pragnąć, skoro inspirowana wiarą chrześcijańską kultura tak głęboko naznaczyła dzieje wszystkich ludów naszej Europy, ludów greckich i łacińskich, germańskich i słowiańskich, mimo wszelkich dziejowych tragedii, ponad systemami społecznymi i ideologiami?" (Przemówienie Jana Pawła II w Parlamencie Europejskim..., dz. cyt.).

19 Homilia w czasie Mszy św. odprawionej na placu Zwycięstwa, 2.06.1979, [w:] Jan Pawet II. Pielgrzymki do Ojczyzny. Przemówienia, homilie, Kraków 2005, s. 25. 
ści Rosji - niespełna 6 milionów. Przestrzeń Unii Europejskiej określana jest na ponad 4 miliony kilometrów kwadratowych ${ }^{20}$. Niemal połowę, a licząc bez Rosji, przeszło dwie trzecie terytorium Europy stanowią więc państwa już zjednoczone. Pozostałe albo nie wyrażają politycznej woli należenia do wspólnoty, choć, poprzez członkostwo w Europejskim Obszarze Gospodarczym, uczestniczą w swobodnym przepływie ludzi, kapitału, towarów i usług (Norwegia, Islandia), albo wybrały integrację w skromniejszym kształcie. Do sprawnego funkcjonowania europejskiego organizmu wystarczy bowiem, iż niektóre państwa umożliwiają chociażby tylko swobodny przepływ osób (Szwajcaria, Lichtenstein, Andora, Watykan). Księstwo Monako, dla potrzeb podatku od towarów i usług, traktowane jest jak terytorium Francji. Dokonywanie dostawy towarów na rzecz podmiotów mających siedzibę w tym państwie będzie zatem traktowane jak wewnątrzwspólnotowa dostawa towarów, a nie eksport. Umożliwia to pełniejszą integrację narodów europejskich zarówno w wymiarze ekonomicznym, jak i aksjologicznym - nawet jeśli pewne kraje formalnie nie są członkami Unii. Nieliczne państwa pozostają zupełnie poza strukturami Unii Europejskiej wbrew swej woli. Nadzieje Jana Pawła II na Europę „dwóch płuc” zostały zatem już spełnione, choć płuco wschodnie nie jest jeszcze do końca wykształcone. Formułowanie postulatów dotyczących dalszej integracji europejskiej może wydawać się zbyt idealistyczne, ale nie jest pozbawione podstaw. Właśnie taka wiara w szczytne cele i posiadanie nadziei na ich realizację leżą u źródeł nauczania Jana Pawła II i powinny towarzyszyć nie tylko jednostkom, ale wręcz całym społecznościom.

\section{Jedna rodzina Europejczyków}

Jan Paweł II wielokrotnie podkreślał, że Europejczycy stanowią rodzinę. Tak bowiem jak bracia mają wspólnych przodków, tak wspólnym mianownikiem dla wszystkich mieszkańców Starego Kontynentu są wspólnie wyznawane wartości. Na gruncie integracji europejskiej budowanie przyszłości nie może ograniczać się jedynie do wspólnego rynku - musi jej towarzyszyć także rozwijanie więzi wręcz braterskiej $^{21}$. Rodzina nie opiera się na prawie silniejszego. Słabszym zapewnia się odpowiednią opiekę i pomoc. Stworzyć w ramach Unii Europejskiej organizację działającą jak rodzina - pełną zaufania, szczerego szacunku, bezinteresownej pomocy świadczonej najsłabszym członkom ${ }^{22}$ : w świecie polityki to niezwykle wy-

20 Źródło: EUROSTAT.

${ }^{21}$ „Wejście w życie systemu zjednoczonego rynku głębiej uświadomiło znacznej części Europejczyków, że stanowią jedną rodzinę i wspólnie uznają wartości wywodzące się z ich bliższej i dalszej przeszłości. Ma to duże znaczenie, ponieważ przyszłości nie można budować jedynie na fundamencie rynku i ekonomii” (Jan Paweł II, Przemówienie podczas noworocznego spotkania z korpusem dyplomatycznym, 16.01.1993).

${ }^{22}$ „Wizja «rodziny» przywodzi na myśl rzeczywistość wykraczającą poza relacje czysto funkcjonalne i poza zwykłą zbieżność interesów. Rodzina jest ze swej natury wspólnotą opartą 
soko postawiona poprzeczka. Słowa takie, niezależnie od momentu dziejowego, wydają się wręcz zbyt przepełnione nadzieją - nadzieją w polityków, w prawodawstwo, w całe społeczeństwa. Niemniej, dwadzieścia lat po ich wypowiedzeniu można zaobserwować wcielanie w życie tak sformułowanych postulatów. Traktatem z Maastricht z 1992 roku wprowadzono unijne obywatelstwo ${ }^{23}$, które należy uznać za nic innego, jak nadanie każdemu Europejczykowi swego rodzaju wspólnego nazwiska. Obywatel państwa członkowskiego nie jest już wyłącznie obywatelem Polski, Danii czy Niemiec, ale, oprócz tego - obywatelem Unii Europejskiej. Jeśli ulegniemy wypadkowi albo zachorujemy podczas pobytu w innym państwie członkowskim, mamy prawo do takiego samego dostępu do opieki zdrowotnej, jak obywatele kraju, w którym przebywamy. Jeśli chcemy, by leczenie naszej choroby odbyło się za granicą - nie ma ku temu przeszkód formalnych. Koszty zostaną pokryte przez naszego ubezpieczyciela, o ile tylko wyrazi na takie leczenie zgodę. Jeśli zostaniemy okradzeni w kraju nienależącym do Unii Europejskiej, w którym nie ma przedstawicielstwa dyplomatycznego lub konsularnego naszego kraju, możemy skorzystać z ochrony udzielonej przez przedstawicielstwo innego państwa członkowskiego. Pożyczka konsularna zostanie udzielona okradzionemu za granicą turyście niezależnie od tego, czy jest on obywatelem kraju udzielającego pomocy. Istotne jest tylko posiadanie obywatelstwa unijnego. Trudno nie dostrzec analogii do relacji obowiązujących w rodzinie. Państwo socjalne powinno dbać o zabezpieczenie społeczne swoich obywateli. Unijne regulacje opierają się bowiem na założeniu całkowitej bezinteresowności państw udzielających pomocy. Obywatel jest przeważnie związany ze swoim krajem, chociażby poprzez podleganie rodzimemu systemowi podatkowemu w stosunku do całości swoich dochodów, niezależnie od miejsca ich osiągnięcia (zgodnie z zasadą rezydencji - o ile tylko nabędzie status rezydenta). Ze względu na finansową partycypację w utrzymywaniu publicznych struktur ma prawo oczekiwać odpowiedniej troski ze strony państwa. Jeśli jednak roztacza się opiekę również nad znajdującymi się w kryzysowym położeniu obywatelami innych państw, można mówić wręcz o matczynej trosce. Wykorzystując działania polegające na zapewnieniu obustronnej pomocy (roztaczanie opieki nad obywatelami państw obcych może być de facto umotywowane oczekiwaniem na odwzajemnienie świadczeń w przyszłości wobec własnych obywateli), kształtuje się sumienia polityków i dba o wprowadzenie dobrych, rodzinnych nawyków w funkcjonowaniu społeczeństw na najwyższym szczeblu - na arenie międzynarodowej. Obywatelstwo unijne to więc nie

na wzajemnym zaufaniu, pomocy i szczerym szacunku. W prawdziwej rodzinie nie panuje prawo silniejszego; przeciwnie, jej słabszym członkom, właśnie ze względu na ich słabość, zapewnia się podwójną opiekę i pomoc». Taki jest prawdziwy sens tego, co w teorii prawa międzynarodowego określa się pojęciem «wzajemności». [...] Każdy naród powinien być gotów dzielić się swymi zasobami ludzkimi, duchowymi i materialnymi, aby nieść pomoc tym, którzy są ubożsi niż on sam" (Jan Paweł II, Przemówienie podczas noworocznego spotkania z korpusem dyplomatycznym, 13.01.1996).

23 Art. 9 Traktatu o Unii Europejskiej, Dz. Urz. UE C 191 z 29.7.1992. 
tylko wspólne nazwisko, ale również widoczne korzyści, które może odczuć każdy z nas. Słabszym zapewnia się pomoc i opiekę, niezależnie od narodowości. Należy zatem $\mathrm{z}$ całą stanowczością stwierdzić, iż papieskie nadzieje są w przedmiotowej materii $\mathrm{w}$ trakcie spełniania.

Postulat stworzenia jednej, europejskiej rodziny odnosi się nie tylko do relacji horyzontalnych pomiędzy jednostkami z poszczególnych państw oraz wertykalnych - pomiędzy obywatelami a władzami publicznymi. Również Państwa Członkowskie powinny traktować siebie nawzajem jak rodzinę. Wspierać najsłabszych, dążyć do zapewnienia zrównoważonego rozwoju, dzielić się zasobami ludzkimi, duchowymi i moralnymi ${ }^{24}$. Celem unijnych polityk spójności, strukturalnej oraz regionalnej, jest wyrównywanie różnic nie tylko pomiędzy Państwami Członkowskimi, ale i poszczególnymi regionami. Jest to uzasadnione koniecznością wzrostu konkurencyjności całej Unii Europejskiej, a nie tylko jej poszczególnych regionów. Ustawodawca unijny tym samym wypełnia nadzieje Jana Pawła II - rodzina będzie silna wówczas, gdy każdy jej członek będzie gotów ponosić trud dla wspólnego dobra. Jeśli dana osoba nie może sprostać wymaganiom - nie porzuca się jej, ale wspomaga rozwój, roztaczając nad nią szczególną opiekę. Regionalny wzrost produktu krajowego brutto w przeliczeniu na jednego mieszkańca w 2011 roku wyniósł dla rumuńskiego regionu Severen Tsentralen zaledwie 31\% średniej europejskiej, dla województwa małopolskiego - 56\%, podczas gdy dla Brukseli - aż $222 \%{ }^{25}$. Nikt nie postuluje odłączenia Severen Tsentralen, czy wręcz całej Rumunii, od Unii Europejskiej. Wprost przeciwnie - region ten może liczyć na szczególną pomoc z funduszy europejskich. Wiąże się to z koniecznością finansowania wzrostu gospodarczego mniej rozwiniętych państw przez te o wyższym stopniu zamożności. Wystarczy wskazać, że w 2013 roku Niemcy na kooperacji z Unią Europejską straciły prawie 14 miliardów euro, podczas gdy Polska zyskała ponad 12 miliardów euro ${ }^{26}$. Jest to jednak cena, jaką lepiej sytuowane podmioty płacą za umocnienie całej rodziny.

\section{Poszanowanie praw człowieka}

Państwo to nie abstrakcyjny byt, istniejący niezależnie od obywateli. To ludzie tworzą poszczególne kraje. Jan Paweł II mocno podkreślał, że każda osoba ma swoją własną historię, a także prawa, których przestrzeganie należy zapewnić27. Prawodawca nie może więc zapominać, że ustanawia normy nie dla anonimowej masy, ale

24 Por. Jan Paweł II, Przemówienie podczas noworocznego spotkania z korpusem dyplomatycznym, 13.01.1996, dz. cyt.

25 Źródło: Opracowanie własne Autora na podstawie danych EUROSTAT.

26 Dane za: http://ec.europa.eu/budget/figures/interactive/index_en.cfm (12.09.2014).

27 „Jak już wielokrotnie podkreślałem, społeczność międzynarodowa gromadzi nie tyle państwa, co raczej narody, złożone z mężczyzn i kobiet, którzy tworzą historię indywidualną i zbiorową. To ich prawa trzeba określić i zabezpieczyć" (Jan Paweł II, Przemówienie podczas noworocznego spotkania z korpusem dyplomatycznym, 13.01.1996, dz. cyt.). 
dla każdego człowieka z osobna - żywej istoty. Nadzieja na uwzględnienie interesu jednostki przy tworzeniu prawa leżała u podstaw nauczania papieża Polaka. Interes ten uwarunkowany jest bowiem szczególną wartością: przyrodzoną i niezbywalną godnością człowieka. W literaturze naukowej stosunek Jana Pawła II do ochrony praw człowieka wyjątkowo trafnie ujmuje prof. dr hab. Tadeusz Jasudowicz - twórca pierwszej w Polsce Katedry Praw Człowieka. Na postawione przez samego siebie pytanie - w którym fragmencie nauczania Jana Pawła II dochodzi do głosu ochrona praw człowieka - odpowiada: „A czy można znaleźć jakikolwiek fragment Jego nauczania, który nie miałby związku z człowiekiem, z jego dowartościowaniem, jego godnością, obroną należnych mu praw?" ${ }^{28}$. Nauczanie to było przy tym przepełnione nadzieją na urzeczywistnienie formułowanych postulatów. Aktualnie można zaobserwować przykładanie coraz większej wagi do poszanowania elementarnych praw każdej istoty ludzkiej. Traktatem lizbońskim zobowiązano Unię do podpisania Konwencji o Ochronie Podstawowych Praw i Wolności - umowy międzynarodowej wypracowanej na gruncie odrębnej organizacji, Rady Europy. Konwencja gwarantuje przestrzeganie przez Państwa-strony praw, takich jak prawo do życia, do rzetelnego procesu sądowego, wolności myśli, sumienia, wyznania. Ustanawia bezwarunkowy zakaz tortur, niewolnictwa, a także innego, nieludzkiego lub poniżającego traktowania. Przystąpienie do Konwencji umożliwi kontrolę aktów prawa unijnego pod kątem zgodności z wypracowanymi przez Radę Europy standardami. Każdy, kto uzna, iż unijne uregulowanie narusza wyrażone w Konwencji prawa, będzie mógł pozwać Unię wprost przed Trybunał w Strasburgu. Traktatem lizbońskim nadano również moc normatywną Karcie Praw Podstawowych. Powyższe wskazuje, iż Unia nie tylko opiera się na wspólnych z nauką chrześcijańską wartościach ${ }^{29}$, ale również dąży do zapewnienia ich bezwarunkowego poszanowania. Zgodnie z dyspozycją artykułu 49 Traktatu o Unii Europejskiej, do wspólnoty może dołączyć wyłącznie państwo europejskie szanujące wartości wyrażone w artykule 2 i zobowiązujące się je wspierać. Prawodawstwo unijne zmierza do poszanowania praw człowieka w każdym aspekcie działalności państw członkowskich: wystarczy wymienić chociażby tylko dyrektywę 2006/54 zapewniającą równe traktowanie kobiet i mężczyzn w zakresie prawa pracy czy dyrektywę 2000/431 traktującą o równości rasowej.

Nadzieje, że chrześcijańskie wartości reprezentowane będą w polityce, gwarantując tym samym poszanowanie godności człowieka, zostały spełnione. Choć

28 T. Jasudowicz, Ochrona praw człowieka w nauczaniu Jana Pawła II, [w:] Jan Paweł II. Prawodawca i stuga prawa Bożego, red. R. Sztychmiler, Olsztyn 2006, s. 93.

29 „Unia opiera się na wartościach poszanowania godności osoby ludzkiej, wolności, demokracji, państwa prawnego, jak również poszanowania praw człowieka, w tym praw osób należących do mniejszości. Wartości te są wspólne Państwom Członkowskim w społeczeństwie opartym na pluralizmie, niedyskryminacji, tolerancji, sprawiedliwości, solidarności oraz na równości kobiet i mężczyzn” (art. 2 Traktatu o Unii Europejskiej, Dz. Urz. UE C 191 z 29.7.1992 z późn. zm.).

30 Dz. Urz. UE L 204 z 26.7.2006.

31 Dz. Urz. UE L 180 z 19.7.2000. 
nie zawsze są bezwarunkowo przestrzegane, ustanowiono odpowiednie mechanizmy gwarancji i kontroli, umożliwiające reakcje na dokonywane naruszenia.

\section{Nadzieja na spełnienie się jeszcze jednej nadziei}

Unia Europejska stanowi na tyle poważne przedsięwzięcie, dotyczące sfery fundamentalnych praw i wolności ludzkich, że formułowanie postulatów pod jej adresem przez władze kościelne było nieuniknione i w pełni uzasadnione. Jan $\mathrm{Pa}$ weł II posiadał własną, wielką wizję integracji europejskiej. Kształt papieskiej Europy zjednoczonej wyrósł wprost $\mathrm{z}$ nadziei na zbudowanie społeczeństwa opartego nie tylko na wzroście gospodarczym, ale również na rozwoju moralności każdej osoby i poszanowaniu jej fundamentalnych praw ${ }^{32}$. Europa ma być wolna i solidarna. Różnorodności narodów ją tworzących ma towarzyszyć jedność polityczna, gospodarcza i monetarna. To dzięki tym wartościom urzeczywistni się cel integracji - korzyść dla każdego człowieka ${ }^{33}$. Wzniosłe papieskie nadzieje pozwalają bowiem nadać sens życiu każdego człowieka z osobna oraz historii narodów. Umożliwiają Europie „pójście razem”34. Idealizm i wiara nie tylko w sprawujących władzę, ale i w całe społeczności, towarzyszące papieskim przemówieniom, wydawały się być nadmierne. Czas jednak pokazał, że pokładane nadzieje nie były pozbawione podstaw. Nadzieja bowiem daje siłę, by realizować cel, jaki zarysowuje. Nawet więc, jeśli postulaty papieskie nie zostały jeszcze zupełnie spełnione, należy dążyć do ich pełnej realizacji poprzez podtrzymywanie wzniosłej wizji Europy. Narody pozbawione wiary w lepsze jutro bardziej boją się bowiem przyszłości, niż jej pragną. Skutkiem tego jest dający się zaobserwować u progu trzeciego tysiąclecia spadek liczby urodzin, kryzys powołań kapłańskich czy instytucji małżeństwa $^{35}$. Choć integracja europejska nie była jedynym przedmiotem papieskiego

32 Por. „Jest rzeczą niezwykle ważną, by w procesie integracji kontynentu wziąć pod uwagę, że jedność nie będzie trwała, jeśli zostanie sprowadzona jedynie do wymiaru geograficznego i ekonomicznego; że musi ona polegać przede wszystkim na harmonii wartości, które winny się wyrażać w prawie i w życiu" (Jan Paweł II, adhort. apost. Ecclesia in Europa, 110).

33 „Wreszcie Unia Europejska ze swym Parlamentem, Radą Ministrów i Komisją proponuje model integracji, która stopniowo się doskonali, z perspektywą, by w przyszłości doszło do przyjęcia wspólnej karty konstytucyjnej. Instytucja ta ma na celu realizację ściślejszej jedności politycznej, gospodarczej i monetarnej państw członkowskich, zarówno obecnych, jak i tych, które w jej skład wejdą. Wspomniane instytucje europejskie w swej różnorodności i dzięki specyficznej tożsamości każdej z nich służą umacnianiu jedności kontynentu, a bardziej jeszcze służą człowiekowi” (tamże, 113).

34 „Podczas trwania Synodu coraz wyraźniejsze stawało się pragnienie nadziei. Ojcowie synodalni, choć zgadzali się z analizą złożonej sytuacji kontynentu, uznali, że zarówno na Wschodzie, jak i na Zachodzie najbardziej chyba palącą kwestią jest wzrastająca potrzeba nadziei, która może nadać sens życiu i historii i pozwala iść razem” (tamże, 4).

35 Por. tamże, 8. 
nauczania, wiążącego się z posiadaniem nadziei ${ }^{36}$, to właśnie jej przykład ukazuje, że na kultywowanie chrześcijańskich wartości oraz posiadanie idealistycznych oczekiwań jest miejsce wszędzie: nawet, a może tym bardziej, w polityce.

Skoro można zaobserwować skuteczne wcielanie w życie tak wielu postulatów formułowanych pod adresem integracji europejskiej, z pozoru nieosiągalnych i bardzo odległych, tym bardziej nie ma przeszkód, by wyrażać nadzieję na spełnienie się jeszcze jednej papieskiej nadziei. By każdy kierujący losami narodów, niezależnie od wyznania, zapatrzony był w św. Tomasza Morusa, ogłoszonego przez Jana Pawła II na progu trzeciego tysiąclecia patronem rządzących i polityków. Stanowi on bowiem źródło inspiracji dla polityki uznającej za najwyższy cel służbę drugiemu człowiekowi. Zwłaszcza człowiekowi słabemu i ubogiemu. Źródło rządzenia, rozumianego jako praktykowanie cnoty, z zachowywaniem głębokiego dystansu wobec zaszczytów i bogactw. Źródło pokory, wspartej „pogodnym i żartobliwym usposobieniem” oraz „trzeźwym spojrzeniem na ulotność sukcesów” ${ }^{37}$. Podobnie jak papież, „ufam zatem, że ogłoszenie Patronem rządzących i polityków postaci tak wybitnej jak św. Tomasz Morus służyć będzie dobru społeczeństwa"38.

\section{Bibliografia}

\section{Literatura}

Benedykt XVI, Encyklika Deus caritas est.

Jan Paweł II, Adhortacja apostolska Ecclesia in Europa.

Jan Paweł II, List apostolski „motu proprio” o ogłoszeniu św. Tomasza Morusa patronem rządzących i polityków.

Jan Paweł II, Przemówienie podczas noworocznego spotkania z korpusem dyplomatycznym, 13.01.1996.

Jan Paweł II, Przemówienie podczas noworocznego spotkania z korpusem dyplomatycznym, 16.01.1993.

Jan Paweł II. Pielgrzymki do Ojczyzny. Przemówienia, homilie, Kraków 2005.

Jasudowicz T., Ochrona praw człowieka w nauczaniu Jana Pawła II, [w:] Jan Paweł II. Prawodawca i stuga prawa Bożego, red. R. Sztychmiler, Olsztyn 2006.

36 Tytułem przykładu: Jan Paweł II formułował nadzieje m.in. na: etyczne korzystanie z efektów rozwoju technologicznego (por. tenże, Przemówienie do Europejskiego Towarzystwa Fizycznego, Rzym, 31.03.1979, [w:] M. Radwan, S. Wylężek, T. Gorzkuła, Jan Paweł II. Wiara i kultura, Rzym-Lublin 1988, s. 27), poszukiwanie przez pracowników naukowych wyłącznie prawdy oraz stanowienie wzoru moralnego dla studentów (por. tenże, Przemówienie do świata uniwersyteckiego, Kinshasa, 4.05.1980, [w:] tamże, s. 36), dążenie dziennikarzy do ukazywania prawdziwego obrazu rzeczywistości, a nie jej naginania, w celu wzbudzenia sensacji (por. tenże, Przemówienie do artystów i dziennikarzy, Monachium, 19.11.1980, [w:] tamże, s. 86).

37 Por. Jan Paweł II, list apost. motu proprio o ogłoszeniu św. Tomasza Morusa..., dz. cyt.

38 Tamże. 
Paweł VI, Encyklika Popolorum progressio.

Przemówienie Jana Pawła II do artystów i dziennikarzy, Monachium, 19.11.1980.

Przemówienie Jana Pawła II do Europejskiego Towarzystwa Fizycznego, Rzym, 31.03.1979.

Przemówienie Jana Pawła II do świata uniwersyteckiego, Kinshasa, 4.05.1980.

Przemówienie Jana Pawła II w Parlamencie Europejskim w Strasburgu, 11.10.1988.

M. Radwan, S. Wylężek, T. Gorzkuła [red.], Jan Paweł II. Wiara i kultura, Rzym-Lublin 1988.

M. Szymczak [red.], Słownik języka polskiego, Warszawa 1979.

\section{Akty prawne}

Traktat o Unii Europejskiej (wersja skonsolidowana), Dz. Urz. UE z dnia 16 października 2012r., C 326.

Traktat o Funkcjonowaniu Unii Europejskiej (wersja skonsolidowana), Dz. Urz. UE z dnia 16 października 2012r., C 326.

Dyrektywa 2006/54/WE Parlamentu Europejskiego i Rady z dnia 5 lipca 2006 r. w sprawie wprowadzenia w życie zasady równości szans oraz równego traktowania kobiet i mężczyzn w dziedzinie zatrudnienia i pracy, Dz. Urz. UE L 204 z 26.7.2006.

Dyrektywa Rady 2000/43/WE z dnia 29 czerwca 2000 r. wprowadzająca w życie zasadę równego traktowania osób bez względu na pochodzenie rasowe lub etniczne, Dz. Urz. UE L 180 z 19.7.2000.

Ustawa z dnia 11 marca 2004 roku o podatku od towarów i usług, T.J. Dz. U. 2011, Nr 177, poz. 1054 z późn. zm.

Inne wykorzystane materiały

http://ec.europa.eu/eurostat (12.09.2014)

http://www.comece.org (12.09.2014)

J. Stróżyk, Palikot chce zamknać usta Kościołowi, „Przewodnik Katolicki” 2010 nr 45, https:// www.przewodnik-katolicki.pl/Archiwum/2010/Przewodnik-Katolicki-45-2010/Spoleczenstwo/Palikot-chce-zamknac-usta-Kosciolowi (12.09.2014).

Kościół a Unia Europejska, http://www.niedziela.pl/artykul/9166/Kosciol-a-Unia--Europejska (12.09.2014)

Papież: dobry katolik miesza się do polityki, http://www.rp.pl/artykul/1048571.html(12.09.2014). Rozpoczęty się Pierwsze Katolickie Dni Społeczne dla Europy, http://magazynfa-milia.pl/drukuj/Rozpoczely_sie_Pierwsze_Katolickie_Dni_Spoleczne_dla_Europy,1927,76.html (12.09.2014).

Artur Tim, Spełnione nadzieje in statu nascendi, [w:] Nadzieja. Nagrodzone i wyróżnione prace konkursowe, red. Katarzyna Dybeł, Zofia Zarębianka, Kraków 2015, s. 50-60 (Dni Jana Pawła II). http://dx.doi.org/10.15633/9788374384650.06 